\title{
Autoreactive and immunoregulatory T-cell subsets in insulin- dependent diabetes mellitus
}

\author{
L. Douglas Petersen ${ }^{1}$, M. van der Keur ${ }^{2}$, R.R.P. de Vries ${ }^{1}$, B.O. Roep ${ }^{1}$ \\ ${ }^{1}$ Departments of Immunohaematology and Blood Bank, University Hospital Leiden, The Netherlands \\ ${ }^{2}$ Department of Clinical Haematology, University Hospital Leiden, The Netherlands
}

\section{Abstract}

Aims/hypothesis. Type I (insulin-dependent) diabetes mellitus is a T-cell mediated autoimmune disease. Several subsets of T-cells, in particular $\mathrm{CD}^{+}$and in vivo activate $\mathrm{CD}_{45 \mathrm{RA}^{+} \mathrm{RO}^{+}} \mathrm{T}$-cells, have been shown to be increased at disease onset. The functional implications of these relative increases in CD4 Tcells were investigated.

Methods. Subsets of T-cells were sorted on the basis of their activation status $\left(\mathrm{CD}^{4} 5 \mathrm{RA}^{+}\right.$naïve cells, $\mathrm{CD} 45 \mathrm{RA}^{+} \mathrm{RO}^{+}$recently activated cells and $\mathrm{CD} 45 \mathrm{RO}^{+}$ memory cells) and stimulated with autoantigens or recall antigen in vitro.

Results. Proliferative responses to tetanus toxoid were primarily or exclusively observed in resting memory T-cells $\left(\mathrm{CD} 45 \mathrm{RO}^{+}\right)$. Autoimmune T-cell responses were, however, primarily measured in activated T-cells $\left(\mathrm{CD} 45 \mathrm{RA}^{+} \mathrm{RO}^{+}\right)$in newly diagnosed Type I diabetic patients, whereas those with longer disease duration reacted to autoantigens with memory T-cells $\left(\mathrm{CD}^{2} 5 \mathrm{RO}^{+}\right)(p<0.004)$. Interestingly, in non-diabetic control subjects not responding to autoantigens in the regular assay, considerable autoreactive T-cell responses were detectable after sorting in the $\mathrm{CD} 45 \mathrm{RO}^{+}$or $\mathrm{CD} 45 \mathrm{RA}^{+} \mathrm{RO}^{+}$lymphocyte subsets. Remixing these subsets showed that these autoimmune responses in activated cells could be downmodulated by CD45RA ${ }^{+}$lymphocytes, whereas resting memory cells appeared unaffected by the suppressive CD45RA subset.

Conclusion/interpretation. These results show that autoimmune T-cell responses can be linked to particular subsets which differ depending on clinical status. Furthermore, the CD45RA T-cell subset harbours lymphocytes potentially capable of suppressing autoimmune T-cell responses. The changes in responsiveness to exogenous insulin may help to unravel the mechanism by which isohormonal therapy could prevent the onset of Type I diabetes. [Diabetologia (1999) 42: 443-449]

Keywords Autoreacitivity, autoimmune disease, regulation, suppression, T-cell subset, CD45.
Type I (insulin-dependent) diabetes mellitus is an autoimmune disease in which the insulin producing pancreatic beta-cells are destroyed [1]. Several lines

Received: 4 September 1998 and in final revised form: 30 November 1998

Corresponding author: Dr. B. O. Roep, Dept. Immunohaematology and Blood Bank, University Hospital Leiden, P. O.Box 9600, 2300 RC Leiden, The Netherlands

Abbreviations: LST, Lymphocyte stimulation test; SI, stimulation index; PBMC, periferal blood mononuclear cells; APC, antigen-presenting cells. of evidence indicate a central role for $\mathrm{T}$ lymphocytes in the pathogenesis of Type I diabetes [2-5]. In humans, autoreactive T-cells responding to insulin, glutamic acid decarboxylase (GAD), 38K and other undefined beta-cell antigens have been described but their role in beta-cell destruction is still not clear [6-11]. We have shown previously that autoimmune T-cells that are reactive with insulin secreting granules are highly detectable in newly diagnosed Type I diabetic patients and also, to a lesser extent, in patients with longer standing Type I diabetes (mean duration of 5 years). Healthy non-diabetic control subjects only occasionally responded [12]. 
It appears that not only the level of reactivity differs between patients with Type I diabetes and control subjects but also the distribution of particular leucocyte subsets. An increased proportion of CD4 positive cells [13-17] and decreased proportion of CD8 positive cells $[14,18]$ in Type I diabetes has been reported by several groups. Additional studies have shown that at diagnosis, Type I diabetic patients have larger numbers of lymphocytes co-expressing the naïve (CD45RA) and the memory (CD45RO) markers [19-21]. We have confirmed and extended these findings in a study on a large number of patients with Type I diabetes and non-diabetic control subjects [22]. The CD45RA ${ }^{+} \mathrm{RO}^{+}$population is assumed to contain lymphocytes activated in vivo and express increased activation markers such as HLA-DR and CD25 [23-26]. The basis for these disease-related alterations in lymphocyte subsets in Type I diabetic patients is not yet known but might be associated with the autoimmune nature of the disease. Furthermore, the abnormal distribution of subsets present in Type I diabetic patients is similar to those observed in other autoimmune diseases such as systemic lupus erythematosus [27], multiple sclerosis [28] and rheumatoid arthritis [29]. Although the underlying aetiologies could differ among the various autoimmune diseases, there seem to be similarities related to alterations in immune regulation.

The functional implications of these abnormalities in of different phenotypes of Type I diabetes are not known, and the possibility that a particular subset of T-cells could be responsible for the autoreactivity seen in Type I diabetes remains to be substantiated. In Type I diabetic patients retrospective comparison of responsiveness in lymphocyte stimulation test (LST) assays with different percentages of subsets $\left(\mathrm{CD}_{45 \mathrm{RA}^{+}}\right.$; CD45RA ${ }^{+} \mathrm{RO}^{+} ; \mathrm{CD}^{2} 5 \mathrm{RO}^{+}$) showed a correlation between toxic tetanus responses and the percentage of memory cells $\left(\mathrm{CD} 45 \mathrm{RO}^{+}\right)$. Furthermore, the percentage of in vivo activated $\mathrm{T}$ cells $\left(\mathrm{CD} 45 \mathrm{RA}^{+} \mathrm{RO}^{+}\right)$correlated with the extent of the reaction against insulin secreting granules in Type I diabetic patients (unpublished data). This could indicate that, rather than reflecting an epiphenomenon, an abnormal distribution of lymphocyte subsets is actually associated with the disease process of Type I diabetes.

Autoreactive T-cells are not unique to Type I diabetic patients but can also be detected in healthy non-diabetic control subjects. We aimed to define the subset of lymphocytes responsible for autoreactivity to islet autoantigens. Furthermore, lymphocytes of non-responding control subjects were divided into subsets on basis of their activation status and subsequently analysed for modulatory capacity. Functional testing of the different subsets (CD45RA, CD45RA/RO and CD45RO) in vitro from patients with recently diagnosed, and long-
Table 1. Characterization of subjects investigated

\begin{tabular}{lllll}
\hline Subject no. & $\begin{array}{l}\text { Sex } \\
\text { (M, male; } \\
\text { F, female) }\end{array}$ & $\begin{array}{l}\text { Age } \\
\text { (years) }\end{array}$ & $\begin{array}{l}\text { Duration } \\
\text { of disease }\end{array}$ & HLA \\
& & & \\
\hline
\end{tabular}

\begin{tabular}{lllll}
\hline \multicolumn{5}{l}{ Newly diagnosed Type I diabetic patients } \\
1 & $\mathrm{M}$ & 5 & 10 days & DR 1,7 \\
2 & $\mathrm{~F}$ & 5 & 25 days & DR 4,7 \\
3 & $\mathrm{~F}$ & 6 & 5 days & DR 3,4 \\
4 & $\mathrm{~F}$ & 0.5 & 2 days & DR 1,3 \\
5 & $\mathrm{M}$ & 13 & 15 days & DR 3,4 \\
Long-standing Type I diabetic patients & & \\
6 & $\mathrm{M}$ & 6 & 3 years & DR 3,4 \\
7 & $\mathrm{M}$ & 6 & 3.5 years & DR 4,5 \\
8 & $\mathrm{~F}$ & 17 & 14.7 years & DR 4,4 \\
9 & $\mathrm{~F}$ & 12 & 8.4 years & DR 3,9 \\
10 & $\mathrm{~F}$ & 7 & 6.2 years & DR 1,4 \\
Non-diabetic control subjects & & \\
11 & $\mathrm{~F}$ & 28 & - & DR 2,2 \\
12 & $\mathrm{~F}$ & 30 & - & DR 2,3 \\
13 & $\mathrm{M}$ & 15 & - & DR 5,6 \\
14 & $\mathrm{~F}$ & 20 & - & DR 4,4 \\
15 & $\mathrm{~F}$ & 27 & - & DR 1,6 \\
\hline
\end{tabular}

standing Type I diabetes, and healthy control subjects were carried out in lymphocyte stimulation test (LST) assays.

\section{Subjects and methods}

Patients. Clinical parameters of the 15 individuals studied are shown in Table 1. After the patients' parents had given informed consent, heparinized blood samples (minimum $30 \mathrm{ml}$ ) were obtained from five children with newly diagnosed Type I diabetes before the first injection of insulin (age range $0.5-13$ years old, mean age 5.9; 3 female). In addition, five long-standing Type I diabetic patients were tested at least 3 years after clinical onset of the disease (age range 5-17 years old, mean age 9.6; 3 female). For ethical reasons, slightly older non-diabetic subjects $(n=5)$ were randomly selected as controls (age range 15-30 years old, mean age 22.0; 4 female). All blood samples were normoglycaemic.

Antigens. An insulinoma membrane preparation obtained from RINm5F rat beta-cell line prepared as described previously [12] was tested at a concentration of $10 \mu \mathrm{g} / \mathrm{ml}$. Insulin (Actrapid; Novo Nordisk, Alphen aan de Rijn, The Netherlands) was denatured and tested at a concentration of $25 \mu \mathrm{g} /$ ml. Tetanus toxoid was obtained from the National Institute of Public Health and Environmental Protection in The Netherlands and tested at a concentration of $12 \mathrm{U} / \mathrm{ml}$.

Lymphocyte subsets. For phenotype analyses of cell surface markers, we used monoclonal antibodies anti-CD45RO (phycoerythrin conjugated) (DAKO, Glostrup, Denmark) and anti-CD45RA (Fluorescein isothiocyanate conjugated) (Becton and Dickinson, Oxford, UK). Peripheral blood mononuclear cells (PBMC) were isolated by Ficoll density gradient centrifugation from $30 \mathrm{ml}$ of freshly drawn heparinized blood. We incubated $10 \times 10^{6}$ cells with saturating amounts of these two monoclonal antibodies for $45 \mathrm{~min}$ at $4{ }^{\circ} \mathrm{C}$, and washed them twice in PBS. The cells were finally sorted after gating 


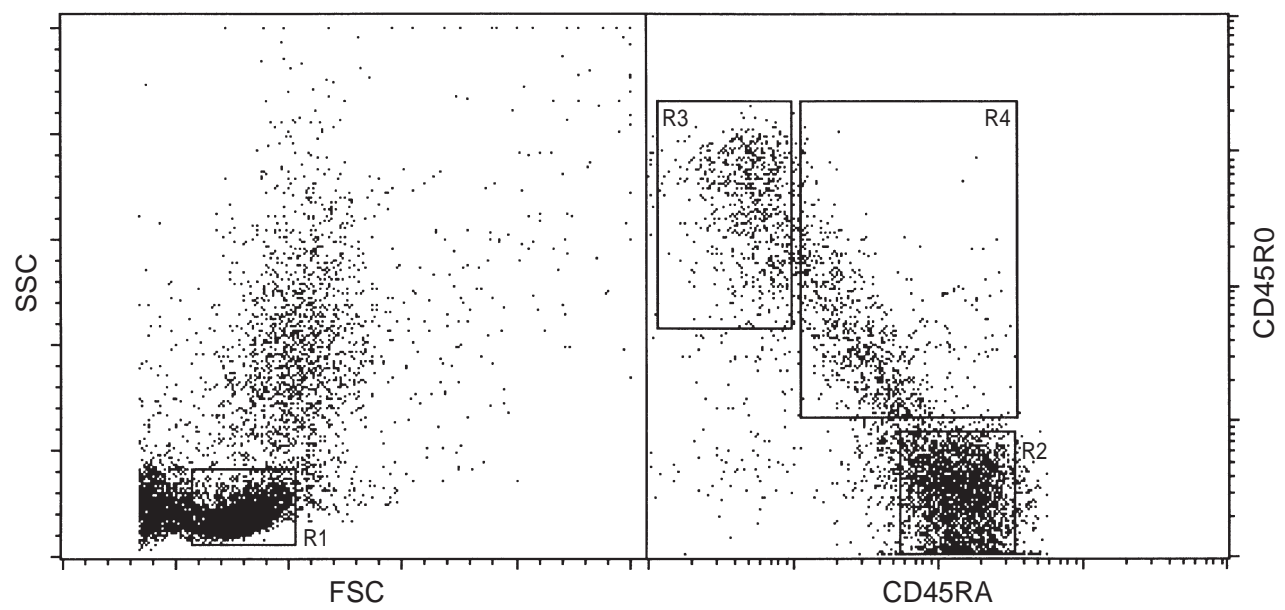

Fig.1. Representative example of FACstar sorter experiment. The lymphocyte fraction was life gated in the forward scatter (FSC) vs side scatter (SSC) dot plot (R1). Gated cells were further divided on the basis of the expression of CD45RA (horizontal axis; R2), CD45RO (vertical axis; R4) or CD45RA/RO double positivity (R3)

the lymphocytes on a FACstar sorter (Becton and Dickinson) and collected in three separated subsets expressing CD45RA, CD45RA and RO, or CD45RO respectively. A representative example of the gate settings is provided in Figure 1.

Simultaneously, $10 \times 10^{6}$ (unstained) peripheral blood mononuclear cells (PBMC) were irradiated (2000 rad) and saved as autologous antigen-presenting cells (APC).

Lymphocyte stimulation assay. Pilot experiments had indicated that the viability of purified PBMC was affected by overnight storage at room temperature before the monoclonal antibody staining procedure. Consequently, the entire experiment was done in one day. The limiting factors in these experiments were the cell recovery after sorting, and the duration of the sorting and plating of the lymphocytes in the tissue culture plates.

Of each subset, $2.5 \times 10^{4}$ cells were cultured in triplicate in round bottom 96 (well) tissue culture plates (Costar, Cambridge, Mass., USA) for 5 days at $37^{\circ} \mathrm{C}, 5 \% \mathrm{CO}_{2}$, in $150 \mu \mathrm{l}$ of Iscove's modified Dulbecco's medium with $2 \mathrm{mmol} / \mathrm{l}$ glutamine (Gibco, Paisley, UK), supplemented with $10 \%$ human type AB pool serum in the presence of either beta-cell membranes, insulin, tetanus toxoid, T-cell growth factor interleukin-2 (10\% Lymphocult, Biotest, Dreieich, Germany) or medium alone. We added $10 \times 10^{4}$ irradiated autologous PBMC as feeders (APC) to each well. In addition, mixing experiments with the different subsets $\left(2.5 \times 10^{4}\right.$ cells per subset $)$ were carried out if sufficient amounts of cells were recovered from the sorting procedure. For comparison, unstained PBMC from each subject were tested in a regular lymphocyte stimulation assay as described previously [12] with $15 \times 10^{4}$ cells per well in the presence of the antigen. After 5 days, $50 \mu \mathrm{l}$ of RPMI1640 (Dutch modification: Gibco) containing $19 \mathrm{KBq}$ $(0.5 \mu \mathrm{Ci})$ of $[3 \mathrm{H}]$ thymidine was added per well and the incubation was continued for $16 \mathrm{~h}$. Cultures were then harvested on glass-fibre filters in an automatic skatron 1105 micro-cell harvester (Skatron, Oslo, Norway). We measured [3H] thymidine incorporation by liquid scintillation counting with an LBK 1205 betaplate counter (Pharmacia, Uppsala, Sweden). The re- sults are expressed as stimulating indices (SI) [cpm in the presence of antigen divided by cpm in the absence of stimulus (medium)]. The distribution of proliferation in the different subsets for all patients was calculated. The mean values of this distribution for each group of subjects are presented in Figure 2 with the mean SI and median for each subset shown within the bars.

\section{Results}

Proliferative responses to tetanus toxiod. In all groups of subjects tested, similar proliferative responses to tetanus toxiod were measured (Fig.2). Proliferation was primarily observed in memory (primed) T-cells $\left(\mathrm{CD} 45 \mathrm{RO}^{+}\right)$. The mean SI for this subset in each group of patients $(\mathrm{SI}=99.3$ in recent onset, 92.9 in post onset Type I diabetic patients and 279.0 in control subjects) was higher than that for the double positive fraction of lymphocytes $\left(\mathrm{CD} 45 \mathrm{RA}^{+} \mathrm{RO}^{+}\right)$ ( $\mathrm{SI}=12,4$ in recent onset, 9.9 in post onset Type I diabetic, and 41.0 in control subjects) $(p<0.05)$. Proliferation of the naïve (unprimed) T-cells $\left(\mathrm{CD} 45 \mathrm{RA}^{+}\right)$ was virtually absent. The relative distribution of proliferation on subset level for the three groups of subjects was not statistically different. The mean SI within the memory cells $\left(\mathrm{CD} 45 \mathrm{RO}^{+}\right)$in Type I diabetic patients was lower than that of the healthy control subjects but this might be explained by the patients being younger than the control subjects and the naïve/memory lymphocyte ratio decrease with increasing age [30]. The relative distribution of responsiveness between the different subsets of lymphocytes reflects, however, the trend that proliferative responses to tetanus toxiod were mainly observed in memory cells $\left(\mathrm{CD} 45 \mathrm{RO}^{+}\right)$.

Proliferative responses to insulin. Newly diagnosed Type I diabetic patients displayed a reactivity pattern that was different to that of patients with long-standing disease $(p<0.004)$ and to non-diabetic control subjects $(p<0.03)$. They responded weakly in the regular LST to insulin (mean SI 3.0; median 3.0) 

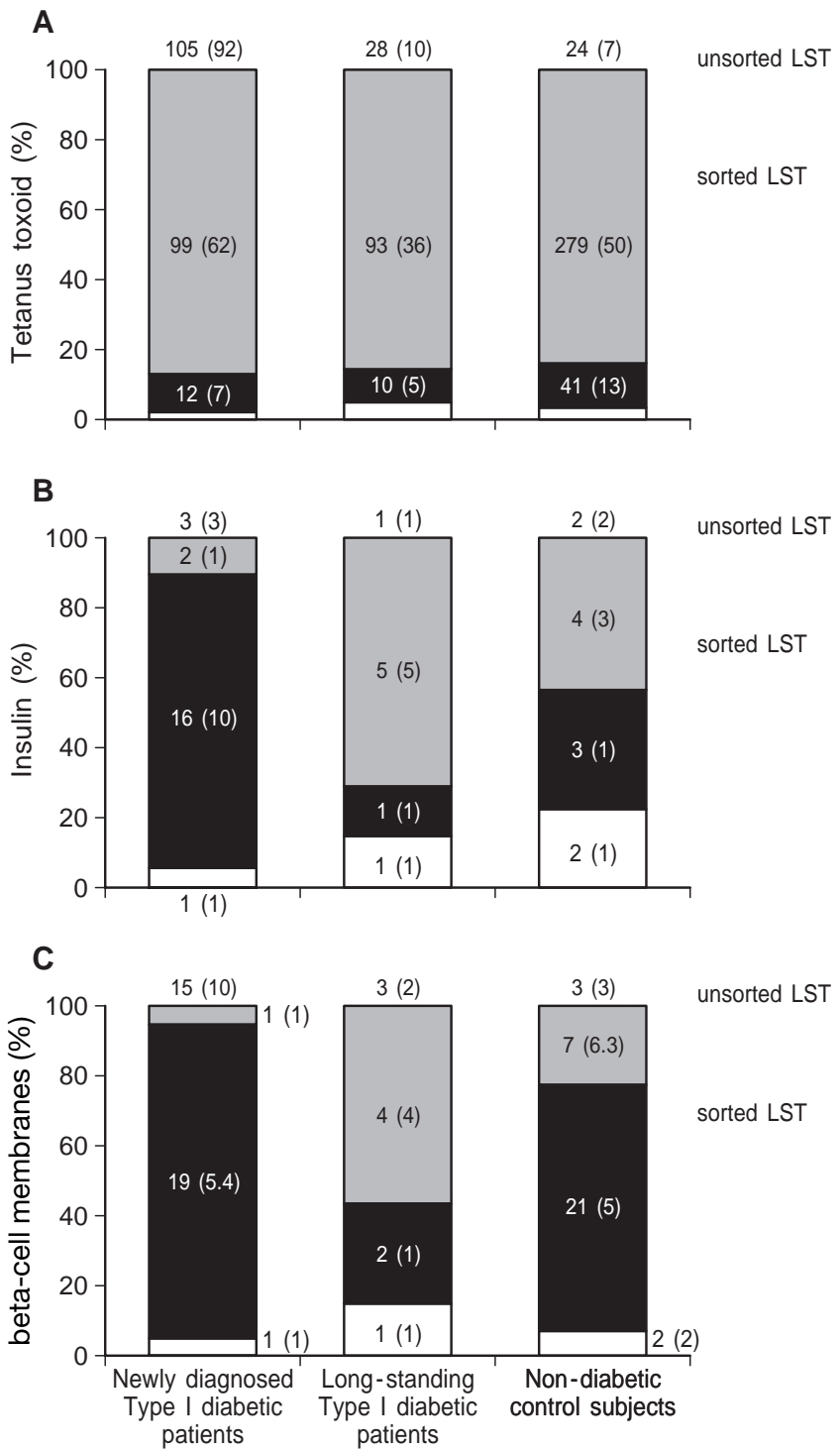

Fig. 2 A-C. Relative contribution of lymphocyte subfractions to proliferative response to tetanus toxoid (A), insulin (B) and beta-cell membrane antigen $(\mathbf{C})$. The bars represent the percentage of the total proliferative reactivity in the fraction of naïve lymphocytes (open boxes), recently activated lymphocytes (black boxes) and memory lymphocytes (hatched boxes). The values expressed are the means of stimulation indices (with medians between brackets) of the response in each of the three subdivisions of lymphocytes in either recently diagnosed Type I diabetic patients $(n=5)$, Type 1 diabetes patients with longer-standing disease $(n=5)$ and non-diabetic control subjects $(n=5)$. The values on top of the bars indicate the proliferative response of unseparated peripheral blood mononuclear cells to each of the three antigen preparations (i.e. regular LST)

(Fig. 2). Autoreactive T-cells co-expressing the CD45RA and CD45RO markers were, however, able to respond strongly to insulin. The mean SI in this group of patients for the activated T-cells

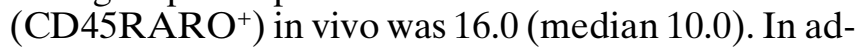
dition, only one newly diagnosed Type I diabetic patient responded to insulin with the single positive

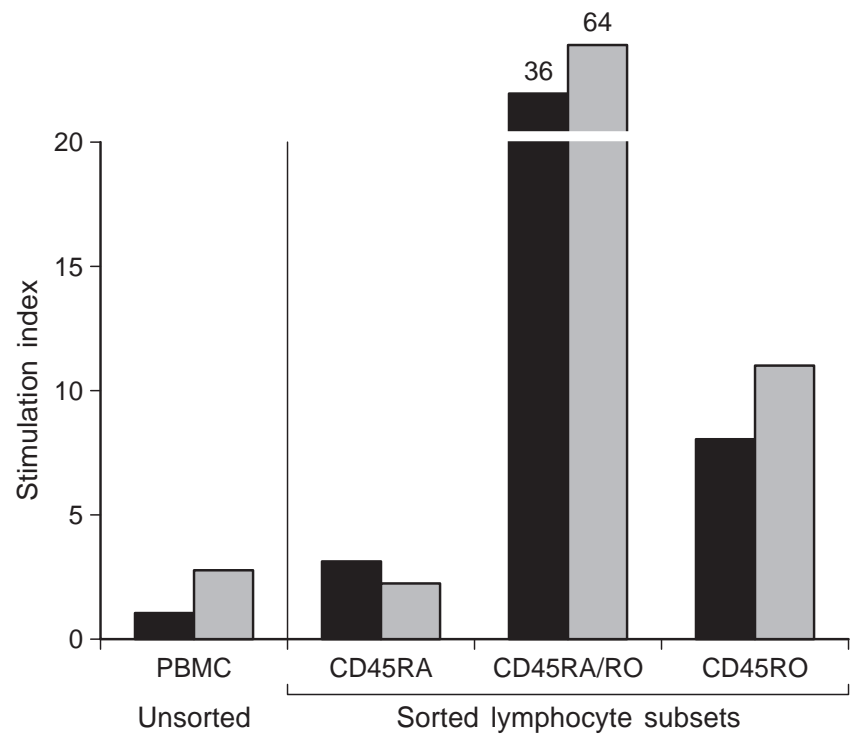

Fig. 3. Proliferative responses of unseparated PBMC and sorted lymphocyte subfractions of two non-diabetic subjects. The data indicate that proliferative responses can be measured in particular subsets of lymphocytes despite nonresponsiveness in the unseparated leucocytes. The values expressed are stimulation indices (response to antigen vs response in medium alone)

CD45RO T-cells (SI 6.0) to insulin. Hardly any proliferation was detectable within the naïve $\left(\mathrm{CD} 45 \mathrm{RA}^{+}\right)$ population of lymphocytes.

Patients with long-standing Type I diabetes did not respond differently from non-diabetic control subjects. As for tetanus toxoid, in patients with longstanding proliferation to insulin Type I diabetes was primarily measured in the $\mathrm{CD}_{4} 5 \mathrm{RO}^{+} \mathrm{T}$-cells (mean SI 5.0, median 4.9). None of these patients showed proliferative responsiveness with double-positive $\mathrm{T}$ lymphocytes $\left(\mathrm{CD} 45 \mathrm{RA}^{+} \mathrm{RO}^{+}\right)$. Naïve T-cells contributed only marginally to the proliferative response.

One non-diabetic subject responded to insulin in the regular standard LST (SI 3.4). On subset level, proliferative responses to insulin were, however, detectable in both the $\mathrm{CD} 45 \mathrm{RO}^{+}$and $\mathrm{CD} 45 \mathrm{RA}^{+} \mathrm{RO}^{+}$ T-cells. The mean stimulation indices for these two subsets were above background levels (mean SI 4.0, median 2.8 and SI 3.0, median 0.9, respectively).

Proliferative responses to insulinoma membranes. Differences in response patterns were observed between newly diagnosed Type I diabetic patients and patients with long-standing disease $(p<0.004)$, but not between diabetic patients (both recent onset and long-standing) and non-diabetic control subjects. Newly diagnosed Type I diabetic patients responded to the beta-cell membrane preparation in the regular LST as described previously [12] (Fig. 2). The mean SI for this group of patients was 15.1, (median 10.1). On subset level, noteable proliferation was almost exclusively observed in activated T-cells $\left(\mathrm{CD} 45 \mathrm{RA}^{+}\right.$ 
$\mathrm{RO}^{+}$) (mean SI 19.1, median 5.4). To the contrary no or only a low level of proliferation was measured in the single positive CD45RA and CD45RO T-cells (mean SI 1.4, median 0.6 and 0.9, median 1.0, respectively).

In contrast, only one patient with long-standing Type I diabetes showed a (marginal) response to insulinoma membranes in the standard LST (mean SI 2.9, median 1.5). This confirmed previous studies $[11,12,31]$. When proliferation was measured on subset level, a shift in responsiveness was, however, observed. Unlike newly diagnosed Type I diabetic patients, those with long-standing disease yielded proliferative responses of memory T-cells $\left(\mathrm{CD} 45 \mathrm{RO}^{+}\right)$ to beta-cell antigen (mean 3.5, median 4.0).

Finally, two non-diabetic control subjects responded in the standard LST to the beta-cell membranes. The mean SI was 3.0 (median 3.2). Furthermore, positive proliferative responses were detected in both the $\mathrm{CD} 45 \mathrm{RA}^{+} \mathrm{RO}^{+}$and $\mathrm{CD} 45 \mathrm{RO}^{+}$subpopulations of lymphocytes (mean SI 21.0, median 4.5; and 7.0, median 6.3, respectively).

Modulation of proliferation responses in healthy nondiabetic control subjects. In two non-diabetic control subjects that were non-responders in the regular LST assay, T-cells autoreactive against beta-cell membrane antigen or insulin were detectable upon sorting into the various subsets (Fig. 3). High proliferation to insulin or insulinoma membranes or both was seen in the double positive $\left(\mathrm{CD} 45 \mathrm{RA}^{+} \mathrm{RO}^{+}\right)$population and also to a lesser extent in the single positive CD45RO T-cells (Fig. 3). When recombining the different subsets in mixing experiments (in 1:1 ratio), the proliferative responses of the recently activated T-cells $\left(\mathrm{CD} 45 \mathrm{RA}^{+} \mathrm{RO}^{+}\right)$could be suppressed almost completely by CD45RA expressing lymphocytes (inhibition 96.8 and $98.7 \%$ for beta-cell membranes and insulin, respectively). In contrast, the proliferative response to recall antigen (tetanus) was not affected by co-culture with naïve lymphocytes. Interestingly, responding autoreactive memory cells $\left(\mathrm{CD} 45 \mathrm{RO}^{+}\right)$ could only be suppressed partially (40.8\% and 3.1\% inhibition of the proliferation to beta-cell antigen and insulin, respectively). The positive autoreactive responses in the CD45RA ${ }^{+} / \mathrm{RO}^{+}$fraction were, however, not affected by addition of equal numbers of cells of the CD45RO ${ }^{+}$subset (data not shown).

Similar mixing experiments were carried out for Type I diabetic patients if sufficient numbers of blood cells were recovered after sorting. Interestingly, two long-standing Type I diabetic patients with positive proliferation in the $\mathrm{CD}^{4} 5 \mathrm{RO}^{+}$memory lymphocyte fraction to insulin or beta-cell antigen contained recently primed activated T-cells $\left(\mathrm{CD} 45 \mathrm{RA}^{+} \mathrm{RO}^{+}\right)$ which were able to down-modulate the autoimmune response to beta-cell membrane antigen or insulin response by $58.2 \%$ and $90.1 \%$, respectively.

\section{Discussion}

The novelty of this study is threefold. Even though we were not able to find differences in T-cell autoreactivity in patients, with either newly diagnosed or long-standing Type I diabetes or in non-diabetic control subjects in unsorted PBMC, we could detect increased autoreactivity to islet autoantigens that differed in all three groups of subjects tested. Firstly, Tcell response to islet autoantigens is almost exclusively present in recently activated lymphocytes of recent onset Type I diabetic patients. Secondly, therapy with exogenous insulin appears to change the autoimmune response to insulin and other beta-cell membranes. Thirdly, regulation of autoimmune T-cells in non-diabetic control subjects and those with long-standing Type I diabetes has been shown. Although the technology applied limited the numbers of subjects that could be studied, the results obtained were remarkably reproducible within groups of subjects with very different patterns of reactivity between these groups.

On the basis of activation status the functional implications of abnormalities in subsets of T-cells could be assigned. After sorting into subsets according to lymphocyte activation status, we noted clear differences in the autoreactive T-cell proliferation between newly diagnosed patients, insulin-treated patients and non-diabetic control subjects. As expected, Tcell reactivity to recall antigen (tetanus toxoid) was detectable in the proportion of memory lymphocytes but not in unprimed T-cells. No qualitative differences were measured between Type I diabetic patients at or after diagnosis or in non-diabetic control subjects. In contrast, proliferation in response to islet autoantigens differed greatly in the three groups studied. The temporary increase in numbers of recently (re)activated T-cells correlated with the temporary increase in islet cell autoreactivity. Autoreactivity of T-cells was most pronounced in recently activated lymphocytes at diagnosis of Type I diabetes, and memory T-cells in patients with long-standing Type I diabetes, whereas non-diabetic control subjects did not show any preferential proliferation to insulin in either naïve, primed or memory lymphocytes. The Tcells of non-diabetic control subjects could, however, respond to rat insulinoma membrane in subsets of lymphocytes despite negative reactivity of unsorted PBMC, suggesting that this response was regulated.

The T-cell reactivity to islet autoantigens changed after cessation of insulitis and exposure to exogenous insulin. These changes were not only to T-cell reactivity to insulin, but also to beta-cell membranes, whereas the immune response to recall antigen (tetanus) was unaffected. Our results suggest that exogenous insulin could cause alterations in diabetes-associated autoreactivity, which might be relevant to the Diabetes Prevention Trial-1 (DPT-1). This trial aims at intervention in the pathogenesis of Type I diabetes by 
subcutaneous or oral immunization with insulin. We have previously reported that Type I diabetic patients treated with insulin for 12 months recognise less insulin epitopes than newly diagnosed Type I diabetic patients [31]. Furthermore, T-cell responses to whole insulin were absent in insulin-treated patients, in contrast to newly diagnosed Type I diabetic patients and non-diabetic control subjects. These data suggest that exogenous insulin can indeed alter immune reactivity. The mechanism of this effect is not known but could involve activation of different subsets of lymphocytes. Alternatively, insulin treatment might stimulate regulatory T-cell subsets. The results of this study imply that regulatory lymphocytes with naïve phenotype do exist. They effectively suppress activated autoreactive T-cells but not inactive or reactivated memory T-cells. It appears that non-diabetic subjects have sufficiently down-modulated autoreactive Tcell responses after sorting, despite the evident autoreactivity of T-cell subsets.

It has been proposed that newly diagnosed Type I diabetic patients have a block in lymphocyte maturation with an accumulation of cells co-expressing CD45RA and CD45RO [19, 32, 33]. It has further been hypothesized that the presence of this subset could be due to temporary T-cell hyperactivation $[21,26]$. Our results confirm that high autoreactivity to both insulin and beta-cell membranes is measurable in recently activated lymphocytes at diagnosis, but is not detectable in memory T-cells of these subjects. This suggests a maturation defect. We also noted, however, that autoreactivity is increased in memory T-cells of patients with long-standing Type I diabetes, in the absence of autoreactivity in recently activated T-cells. This could imply that lymphocytes primed and activated at diagnosis mature to resting memory T-cells after Type I diabetes is established. Alternatively, a different (regulatory) subset of lymphocytes might have become primed and activated upon exposure to exogenous insulin injections, thereby explaining the autoreactivity in the memory lymphocyte fraction in patients with long-standing Type I diabetes.

Testing the different subsets from healthy subjects showed that they, as well as Type I diabetic patients, have autoreactive T-cells but these appear to not respond in regular (i.e. unsorted) proliferation assays. Both the memory and recently activated T-cells proliferated in the presence of either insulinoma membranes or insulin although proliferation in the regular LST for these subjects was not evident. This implies that autoreactive T-cells in healthy subjects in vivo are modulated so that responsiveness to any self antigens is prevented. The mechanism by which such modulation is achieved is not clear. It has been proposed that primed autoreactive T-cells die upon stimulation with antigen in order to prevent them from maturating into active autoreactive T-cells [34]. Fur- thermore, it has been shown that some lymphocytes elicit suppressor function. Decrease or absence of these cells could result in the activation of autoreactive T-cells [27]. In our remixing experiments where combinations of subsets were tested with the different antigens, we show that the aberrant autoimmune response in the healthy control subjects could be down-modulated by CD45RA ${ }^{+}$expressing lymphocytes. The suppression primarily seemed, however, to be effective for recently activated lymphocytes, rather than resting memory cells. This notion was supported by the observation that the response to the recall antigen tetanus was not affected by addition of the regulatory subset of lymphocytes. That CD45RA positive lymphocytes may elicit a suppressor function has been reported previously [27]. Very recently, it was reported that treating patients with multiple sclerosis with depleting CD4 monoclonal antibody was ineffective because of the preferential loss of circulating naïve $\left(\mathrm{CD}^{4} \mathrm{RA}^{+}\right) \mathrm{T}$-cells [35]. This observation is in line with our data. Although the lack of T-cell responses in $\mathrm{CD}_{45 \mathrm{RA}^{+}}$lymphocytes is consistent with a naïve phenotype, there is evidence to show that a fraction of these cells have been previously activated, as is illustrated by the expression of Fas [35]. This implies that the switch in phenotype is not unidirectional, as $\mathrm{CD}^{2} 5 \mathrm{RO}^{+}$lymphocytes can switch back to $\mathrm{CD}^{2} 4 \mathrm{RA}^{+} / \mathrm{RO}^{-}$phenotype after a prolonged absence of antigen [36].

Acknowledgements. We wish to thank Drs. N. Schloot, F. Claas and A. Brand for critically reading this manuscript, and Mrs. G. Duinkerken for expert technical assistance. This study was supported by grants from the Juvenile Diabetes Foundation International, the Diabetes Fonds Nederland and the Danish Research Council. Dr. B. Roep is fellow of the Royal Academy of Arts and Sciences, The Netherlands.

\section{References}

1. Eisenbarth GS (1986) Type I diabetes mellitus. A chronic autoimmune disease. N Engl J Med 314: 1360-1368

2. Bottazzo GF, Dean BM, McNally JM, MacKay EH, Swift PGF, Gamble DR (1985) In Situ Characterization of Autoimmune Phenomena and expression of HLA Class II Molecules in the Pancreas in Diabetic Insulitis. N Engl J Med 313: 353-360

3. Roep BO (1996) Perspectives in Diabetes: T-cell responses to islet autoantigens in insulin-dependent diabetes mellitus: The search for the Holy Grail. Diabetes 45: 1147-1156

4. Lampeter EF, Homberg M, Quabeck K et al. (1993) Transfer of insulin-dependent diabetes between HLA-identical siblings by bone marrow transplantation. Lancet 341: 1243-1244

5. Sibley R, Sutherland DER, Goetz F, Michael AF (1985) Recurrent diabetes mellitus in the pancreas iso- and allograft. A light and electron microscopic and immunohistochemical analysis of four cases. Lab Invest 53: 132-144

6. Roep BO, Kallan AA, Hazenbos WL et al. (1991) T-cell reactivity to $38 \mathrm{kD}$ insulin-secretory-granule protein in pa- 
tients with recent-onset type 1 diabetes. Lancet 337: 1439-1441

7. Roep BO, Arden SD, De Vries RRP, Hutton JC (1990) Tcell clones from a type-1 diabetes patient respond to insulin secretory granule proteins. Nature 345: 632-634

8. Neophytou PI, Roep BO, Arden SD et al. (1996) T-cell epitope analysis using substracted expression libraries (TEASEL): Application to a $38-\mathrm{kDa}$ autoantigen recognized by T-cells from an insulin-dependent diabetic patient. Proc Natl Acad Sci USA 93: 2014-2018

9. Naquet P, Ellis J, Tibensky D et al. (1988) T cell autoreactivity to insulin in diabetic and related non-diabetic individuals. J Immunol 140: 2569-2578

10. Atkinson MA, Kaufman DL, Campbell L et al. (1992) Response of peripheral-blood mononuclear cells to glutamate decarboxylase in insulin-dependent diabetes. Lancet 339: 458-459

11. Honeyman MC, Cram DS, Harrison LC (1993) Glutamic acid decarboxylase 67-reactive T cells: a marker of insulindependent diabetes. J Exp Med 177: 535-540

12. Roep BO, Kallan AA, Duinkerken G et al. (1995) T-cell reactivity to beta-cell membrane antigens associated with beta-cell destruction in IDDM. Diabetes 44: 278-283

13. Buschard K, Ropke C, Madsbad S, Mehlsen J, Rygaard J (1983) T lymphocyte subsets in patients with newly diagnosed type 1 (insulin-dependent) diabetes: A prospective study. Diabetologia 25: 247-251

14. Ilonen J, Surcel HM, Kaar ML (1991) Abnormalities within CD4 and CD8 T lymphocytes subsets in type 1 (insulindependent) diabetes. Clin Exp Immunol 85: 278-281

15. Legendre CM, Schiffrin A, Weitzner G, Colle E, Guttmann RD (1988) Two-color flow cytometry analysis of activated T-lymphocyte subsets in Type 1 Diabetes mellitus. Diabetes 37: 792-795

16. Peakman M, Alviggi L, Hussain MJ et al. (1994) Increased expression of T-Cell markers of immunological memory associated with protection from type I diabetes - A study of identical twins. Diabetes 43: 712-717

17. Al-Kassab AS, Raziuddin S (1990) Immune activation and $\mathrm{T}$ cell subset abnormalities in circulation of patients with recently diagnosed type I diabetes mellitus. Clin Exp Immunol 81: 267-271

18. Buchard K, Röpke C, Madsen S, Mehlsen J, Sorensen TB, Rygaard J (1983) Alterations of peripheral T-lymphocyte subpopulations in patients with insulin-dependent (type 1) diabetes mellitus. J Clin Lab Immunol 10: 127-131

19. Faustman DL (1993) Occult CD45 T Cell Developmental Defect in Type 1 Diabetes. Diabete et Metabolisme 19: 446-457

20. Smerdon RA, Peakman M, Hussain MJ et al. (1993) Increase in Simultaneous Coexpression of Naive and Memory Lymphocyte Markers at Diagnosis of IDDM. Diabetes 42: 127-133

21. Peakman M, Warnock T, Vats A et al. (1994) Lymphocyte Subset Abnormalities, Autoantibodies and Their Relationship with HLA Dr Types in Children with Type 1 (InsulinDependent) Diabetes and Their First Degree Relatives. Diabetologia 37: 155-165
22. Douglas Petersen L, Duinkerken G, Bruining GJ, van Lier R, De Vries RRP, Roep BO (1996) Increased numbers of in vivo activated T-cells in patients with recent onset diabetes mellitus. J Autoimmun 9: 731-737

23. Prince H, E, York J, Jensen ER (1992) Phenotypic comparison of the three populations of human lymphocytes defined by CD45RO and CD45RA expression. Cell Immuno 145: 254-262

24. Rothstein DM, Yamada A, Schlossmann SF, Morimoto C (1991) Cyclic regulation of CD45 isoform expression in a long term human CD4 + CD45RA + T cell line. J Immuno 146: 1175-1183

25. Matsuyama T, Yamada A, Rothstein DM, Anderson KC, Schlossman SF, Morimoto C (1991) CD45 isoforms associated with distinct functions of CD4 cells derived from unusual healthy donors lacking CD45RA-T lymphocytes. Cell Immunol 137: 406-419

26. Peakman M, Mahalingam M, Leslie RD, Vergani D (1994) Co-expression of CD45RA (naive) and CD45R0 (memory) T-cell markers [letter]. Lancet 343: 424

27. Morimoto C, Hafler DA, Weiner HL et al. (1987) Selective loss of the suppressor-inducer $\mathrm{T}$ cell subset in progressive multiple sclerosis: analysis with anti-2H4 monoclonal antibody. N Eng J Med 316: 67-73

28. Morimoto C, Steinberg AD, Letvin NL et al. (1987) A defect of immunoregulatory $\mathrm{T}$ cell subsets in systemic lupus erythematosus patients demonstrated with anti-2H4 antibody. J Clin Invest 79: 762-763

29. Summers KL, O'Donnell JL, Hart DNJ (1994) Co-expression of the CD45RA and CD45R antigens on T lymphocytes in chronic arthritis. Clin Exp Immunol 97: 39-44

30. de Jong R, Brouwer M, Hooibrink B, Pouw-Kraan TV, Miedema F, van Lier RAW (1992) The CD27-subset of peripheral blood memory CD4 + lymphocytes contains functionally differentiated $\mathrm{T}$ lymphocytes that develop by persistent antigenic stimulation in vivo. Eur J Immunol 22: 993-999

31. Schloot NC, Roep BO, Wegmann D et al. (1997) Altered immune response to insulin in newly diagnosed versus insulin treated diabetic patients and healthy control subjects. Diabetologia 40: 564-572

32. Faustman D, Schoenfeld D, Ziegler R (1991) T-lymphocyte changes linked to autoantibodies. Association of insulin autoantibodies with CD4 + CD45R + lymphocyte subpopulation in prediabetic subjects. Diabetes 40: 590-597

33. Faustman D, Eisenbarth G, Daley J, Breitmeyer J (1989) Abnormal T-lymphocyte subsets in type I diabetes. Diabetes 38: $1462-1468$

34. Matzinger P (1994) Tolerance, danger, and the extended family. Annu Rev Immunol 12: 991-1045

35. Rep HMG, Van Oosten BW, Roos MTL, Ader HJ, Polman CH, van Lier RAW (1997) Treatment with depleting CD4 monoclonal antibody results in a preferential loss of circulating naive T-cells but does not affect IFN-g secreting TH1 cells in humans. J Clin Invest 99: 2225-2231

36. Bell EB, Sparshott SM, Bunce C (1998) CD4 + T-cell memory, CD45R subsets and persitence of antigen - a unifying concept. Immunol Today 19: 60-64 